\title{
Kegiatan Menganyam dengan Bahan Alam untuk Mengembangkan Kemampuan Motorik Halus Anak
}

\author{
Meriyati $^{\circledR}$, Cahniyo Wijaya Kuswanto ${ }^{2 凶}$, Dona Dinda Pratiwi ${ }^{3 凶}$, Ela Apriyanti ${ }^{4 \bowtie}$ \\ Pendidikan Islam Anak Usia Dini, Universitas Islam Negeri Raden Intan Lampung $(1,2,4)$ \\ Pendidikan Matematika, Universitas Islam Negeri Raden Intan Lampung (2) \\ DOI: $\underline{10.31004 / o b s e s i . v 5 i 1.667}$
}

\begin{abstract}
Abstrak
Koordinasi mata, tangan, dan jari-jemari membutuhkan kecermatan dan ketelitian dalam pembiasaaan dan pengendalian gerak motorik halus anak usia dini.Salah satu kegiatan motorik halus dapat distimulus dengan kegiatan menganyam menggunakan bahan alam. Penelitian ini bertujuaan untuk mengetahui pengaruh kegiatan menganyam terhadap perkembangan motorik halus anak usia dini. Quasi Eksperimen menjadi metode dalam penelitian ini dengan desain nonequivalent control group design. Subjek penelitian ini anak usia 5-6 tahun, yaitu kelompok B1 kelas eksperimen dan B2 kelas kontrol. Untuk uji hipotesis pada penelitian ini menggunakan uji-t berbantu program SPSS V.21. Berdasarkan hasil uji $t$ dengan uji Independent sample $t$ test, nilai signifikansi < 0,05 artinya $\mathrm{H} 1$ diterima dan $\mathrm{H} 0$ ditolak, dengan demikian dapat disimpulkan bahwa kegiatan menganyam berpengaruh terhadap pekembangan motorik halus anak kelompok B usia 5-6 tahun. Hasil tersebut dapat digunakan menjadi salah satu alternatif pembelajaran dalam mengembangkan motorik halus anak usia dini.
\end{abstract}

Kata Kunci: motorik halus; kegiatan menganyam; anak usia dini

\begin{abstract}
Coordination of the eyes, hands and fingers requires carefulness and accuracy in the use and control of fine motor movements in early childhood.One of the fine motor activities can be stimulated by weaving activities using natural materials. This study aims to determine the effect of weaving activities on the development of fine motor development in early childhood. Quasi Experiment became the method in this study with the nonequivalent control group design. The subjects of this study were children aged 5-6 years, namely the B1 group in the experimental class and B2 in the control class. To test the hypothesis in this study using t-test assisted by SPSS V.21 program. Based on the results of the test with the Independent sample $t$ test, obtained sig ( 2 tailed) value of 0,000 based on decision making if the significance value $<0.05(5 \%)$ then $\mathrm{H} 1$ is accepted and $\mathrm{H} 0$ is rejected, thus it can be concluded that the weaving activity influences the fine motor development in children group $B$ ages 5-6 years. These results can be used as an alternative learning in developing fine motor skills in early childhood.
\end{abstract}

Keywords: fine motor; weaving activities; early childhood

Copyright (c) 2020 Meriyati, Cahniyo Wijaya Kuswanto, Dona Dinda Pratiwi, Ela Apriyanti

$\triangle$ Corresponding author :

Email Address : cahniyo.wijaya@radenintan.ac.id (Lampung, Indonesia)

Received 17 July 2020, Accepted 8 August 2020, Published 14 August 2020 


\section{PENDAHULUAN}

PAUD (Pendidikan Anak Usia Dini) suatu pendidikan yang didalamnya bertujuan untuk memberikan fasilitas baik itu untuk aspek pertumbuhan maupun seluruh aspek perkembangan masa anak-anak. Pada hakikatnya pelaksanaan pendidikan yang terjadi pada anak usia dini ini menitikberatkan pada semua aspek perkembangan yang terdapat pada anak ada beberapa yaitu meliputi perkembangan kognitif, nilai agama dan moral, bahasa, sosial emosional, seni serta fisik dan motorik. Kegiatan yang dilaksanakan di lembaga pendidikan anak usia dini perlu dilaksanakan keseluruhan dengan demikian dapat mengembangkan seluruh potensi yang terdapat anak secara optimal dan juga untuk persiapan anak dalam menjalankan proses pendidikan dimasa yang akan mendatang (Anggraini \& Kuswanto, 2019; Nurhayati, 2015; Udin, 2015).

Pendidikan anak usia dini juga salah satu dasar maupun elementer untuk dijadikan kerangaka utama yang akan diproses dan berkembangnya suatu kerangka dasar pengetahuan, keterampilan maupun perilaku pada anak (Amalia, 2016; Masdudi, 2015; Sintia et al., 2019). Berbagai aspek pertumbuhan dan perkembangan banyak yang berkaitan erat dengan anak usia dini yaitu tumbuh kembang yang terdapat pada anak usia dini sangat penting di stimulus sedini mungkin yaitu salah satunya perkembangan motorik. Aspek perkembangan ini terbagi menjadi dua yaitu perkembangan motorik kasar dan perkembangan motorik halus.

Perkembangan motorik meliputi motorik kasar dan motorik halus". Artinya motorik kasar berhubungan dengan perkembangan otot kasar seseorang mampu menyelaraskan contohnya melempar, melompat, berlari dan berjalan (Wijaya Kuswanto \& Dinda Pratiwi, 2020). Untuk motorik halus sendiri adalah suatu gerak yang melibatkan penggunaan otot yang halus selain itu bagian anggota tubuh tertentu, kesempatan untuk latihan dan mencoba belajar dapat mempengaruhi hal tersebut (Rakimahwati et al., 2018).

Kegiatan motorik halus tidak terlalu membutuhkan tenaga cukup yang besar melainkan dengan menggunakan otot-otot halus saja. Hal tersebut didukung oleh beberapa ahli yang mengemukakan demikian, motorik halus menurut Moelichatoen adalah salah satu kegiatan keterampilan bergerak yang melibatkan penggunaan otot-otot halus pada jaringan tangan dan jari-jemari, sedangkan Hurlock mengemukakan bahwa motorik halus adalah gerakan yang menggunakan otot-otot halus atau tidak seluruh anggota tubuh tertentu, yang dipengaruhi oleh kesempatan untuk belajar dan berlatih. Susanto mengatakan motorik halus adalah suatu gerakan halus yang melibatkan penggunaan sebagian tertentu saja yang dikerjakan oleh otot-otot halus atau kecil saja, Karena tidak terlalu memerlukan tenaga yang besar. Namun dengan begitu gerakan yang halus ini membutuhkan harmonisasi mata tangan dengan cekatan dan tepat (Faizatin, 2018).

Sujiono berpendapat kegiatan motorik halus merupakan kemampuan gerakan yang melibatkan otot-otot kecil yang terdiri dari koordinasi mata dan tangan yang terkoordinasi dengan sama rata sehingga menciptakan suatu keterampilan. Dalam cara kerjanya gerakan motorik halus tidak terlalu membutuhkan banyak tenaga melainkan hanya melibatkan koordinasi mata dan gerakan tangan yang cermat. Pada anak yang cukup bagus dalam kematangan motorik halus akan menunjukkan kegiatan kemandirian dikarenakan tangannya 
sudah dapat terampil untuk melakukan berbagai kegiatan yang berhubungan dengan motorik halus (Berti Setya N, Farida Mayar, 2019; Darmiatun \& Mayar, 2019).

Perkembangan motorik halus jika dikembangkan dengan baik akan berpengaruh terhadap kehidupan individu, baik yang berhubungan dengan kehidupan sehari-sehari sepeti mengancingkan baju, mengikat tali septu dll maupun pada bidang pendidikan seperti menulis, mewarnai dll. Keterampilan motorik halus adalah keterampilan yang melibatkan gerakan yang diatur sedemikian rupa secara halus. Mengancingkan baju, membuka dan menutup reseleting, menggenggam mainan, maupun melaksanakan kegiatan apa pun yang membutuhkan kemampuan keahlian tangan membuktikan kepandaian motorik halus (Maulida, 2020; Rudiyanto, 2016).

Menurut Papilia, Olds, Feldman motorik halus dalam perkembangannya yaitu suatu keahlian fisik motorik dengan mengikutsertakan otot yang halus serta koordinasi antara mata serta bagian tangan. Beberapa contoh aktivitas motorik halus adapun sebagai berikut: menggambar, mengancingkan baju, serta koordinasi mata dan otot yang halus. Lambat laun dengan kematangan perkembangan kemampuan motoriknya, anak usia prasekolah secara terus menerus dan berksinambungan dalam menggabungkan kemampuan yang telah mereka dapatkan dan miliki dengan kemampuan yang mereka dapatkan untuk menghasilkan kapasitas yang lebih rumit (Maulida, 2020; Rudiyanto, 2016).

Kemampuan motorik halus menggambarkan suatu gerak dengan melibatkan bagian otot yang halus atau tidak keseluruhan bagian-bagian tubuh tertentu saja yang bisa saja dipengaruhi oleh keinginan serta kemauan untuk mencoba dan berlatih (Wiyani, 2016). Untuk bagian kemampuan motorik halus seorang anak, khususnya anak usia dini mampu melakasanakan harmonisasi antara gerak anggota tubuh yang mengikutsertakan mata dan bagian tangan untuk dapat melakukan kegiatan yang berkaitan erat dan juga yang berhubungan dengan gerak pada bagian tangan. Keahlian dalam motorik halus ini terdapat beberapa contoh kegiatan, menumpuk mainan seperti lego ataupun balok mainan, menggunting, mengepalkan tangan, memegang benda-benda, merobekan kertas, membentuk lipatan dari kertas, mewarnai pola gambar, menggambar bebas sesuai dengan keinginannya ataupun bisa diarahkan, menebalkan pola, menulis dan lainnya.

Gerakan-gerakan yang terdapat pada motorik halus membutuhkan pengendalian bagian otot-otot ukuran kecil atapun halus sehingga dengan dmikian mampu mencapai tujuan yang sesuai dengan konsep yang dituju dengan membutuhkan pengorganisasian antara bagian mata dan tangan serta kegiatankegaiatan yang membutuhkan gerakan tangan atau jari-jari untuk kegiatan dengan menggunakan konsestrasi yang baik. Jadi motorik halus meliputi penggunaan dan kontrol otot kecil seperti menggunting, menggambar, mewarnai dan lain-lain (Rudiyanto, 2016).

Pentingnya mengembangkan kemampuan motorik halus anak. Masganti berpendapat bahwa ada empat alasan mengenai urgensi kemampuan motorik halus pada anak dapat berkembang:

(a) Alasan pada aspek sosial: sejumlah keterampilan yang bermanfaat perlu untuk dipelajari setiap anak, kegiatan tersebut seperti makan makanannya sendiri tanpa adanya bantuan, mengenakkan pakaian, aktivitas toilet training dan membersihkan diri sendiri (menggosok gigi, keramas serta merapikan rambut). Adapun umumnya setiap anak mampu melakukan beberapa aktivitas tersebut, hal tersebut mampu 
tercapai jika seorang individu/anak memiliki kemauan dan keinginan untuk menirukan kegiatan yang sudah diberikan latihan atau contoh oleh orang-orang dilingkungan sekitar. Contohnya seorang anak mengalami mendapatkan ketidakmampuan untuk bisa menguasai dan memahami keahlian itu akan merasa lebih sulit menyelaraskan susunan kegiatan yang sudah ada jika saja dibandingkan pada anak-anak yang telah lebih dahulu mampu melaksankan hal tersebut, (b). Alasan pada bidang akademis: berbagai aktivitas contohnya saja yang terdapat disekolah memerlukan kinerja keterampialn motorik halus, seperti menggunting, menulis, dan memegang bebagai alat yang membutuhkan ketelitian khusus seperti dalam aktivitas uji sains permulaan. Seorang anak diharuskan mampu secara langsung dapat mengendalikan harmonisasi yang baik antara mata dan juga bagian tangan. (c). Alasan pada bidang vokasional / pekerjaan: berbagai macam profesi seseorang membutuhkan beberapa keahlian yang melibatkan motorik halus contohnya pada profesi sekretaris, petugas arsip, guru dan lain sebagainya. Keahlian motorik halus pada seseorang sudah berkembang, maka banyaknya kendala yang dialami pada profesi tersebut sehingga mampu diminimalisir sedemikian rupa. (d). Alasan psikologis: anak-anak yang telah mempunyai pengorganisasian pada bagian motorik halus yang terbilang baik kemungkinan kecil akan mengalami kendalakendala contohnya penyesuaian dengan aktivitas yang sudah diketahui sebelumnya contohnya kegiatan sehari-hari yang mengikutsertakan kegiatan motorik yang halus/kecil. Berbeda halnya dengan anak yang memiliki pengorganisasian yang dapat dikatakan kurang bagus akan mengarah pada sikap lebih cepat mengalami kekecewaan, merasa dirinya tidak berhasil, dan menganggap tidak diterima karena ketidak mampuannya. Kondisi ini akan memberikan pengaruh yang kurang baik terhadap persepsi diri berusaha menjauhi perilaku yang mereka anggap kurang mampu untuk dikerjakan. (Sit, 2017, p. 119) .

Dari uraian yang dikemukakan diatas dapat diketahui bahwa pentingnya perkembangan motorik halus pada anak usia ini begitu penting, terlebih jika salah satu aspek perkembangan yaitu motorik halus di stimulus sejak dini dikarenakan anak usia dini merupakan masa keemasan atau peniru yang ulung karena masih sangat kecil (golden age) dapat berpengaruh dan bermanfaat dikehidupan mendatang. Karena banyak aktifitas maupun kegiatan yang memerlukan perkembangan motorik halus anak ada yang berhubungan dengan pemanfaatan jarijemari dan tangan, pergelangan pada tangan dan juga koordinasi yang terjadi antara mata serta tangan anak.

Menurut (Yuningsih \& Hasanah, 2018) kemampuan motorik halus seseorang mencakup gerakan yang mengikutsertakan bagian otot yang halus dan membutuhkan upaya pengoorganisasian baik itu indra penglihat yaitu mata dan juga tangan. Motorik halus pada anak dikatan sudah berkembang apabilah telah menguasai keahlian-keahlian anak ketika memperlihatkan dan telah mampu melakukan gerak pada otot yang bagus dalam konsep koordinasi, kecekatan serta ketangkasan pada penggunaan bagian tangan serta jari-jari tangan. Anak terbiasa menjelajah sesuai keinginannya pada kemampuan motoriknya pasca ia lahir kedunia. Mempunyai kesempatan-kesempatan gerak yang didasari oleh kemauannya.

Semua aspek perkembangan yang ada pada anak tentu memerlukan stimulus untuk mecapai keberhasilan tertentu, bermacam aktivitas dalam melatih perkembangan keterampilan motorik halus diantaranya : mengikat tali sepatu, 
meronce, melipat, menggunting, mengarsir, mewarnai pila gambar, menempel dan menganyam, tentu saja kegiatan-kegitan tersebut berhubungan erat dengan penggunaan otot yang halus, keterampilan jari jermari, pergelangan tangan serta pengorganisasian antara mata dan juga (Rudiyanto, 2016; Sari \& Nofriyanti, 2019)

Kegiatan menganyam adalah contoh seni tradisional dengan ciri khusus yang dimiliki oleh negara Indonesia. kegiatan anyaman ini bagian dari karya seni tradisi yang masih dipertahakan dan dikerjakan hingga masa sekarang oleh masyarakat, disamping banyak fungsinya juga memiliki komponen dari pendidikan. Maka anak usia dini kegiatan menganyam ini sudah diperkenalkan dan juga diajarkan guna melatih disamping melatih sikap anak juga motorik halus (Hajar Pamadhi, 2008, p. 6.38).

Kegaiatan menganyam bagian dari kegiatan yang didalamnya pengembangan dikarenkan memiliki aktivitas membiasakan motorik halus dengan tujuan mengekspresikan daya imajainasi sehingga anak dapat menciptakan hal yang baru yang dilandasi oleh daya hayal anak yang menggunakan keuletan, teliti, dan keluwesan oleh karena itu perlu dikerjakan dengan penuh rasa sabar, hal tesebut karena didalamnya memiliki suatu unsur yaitu keindahan serta seni. Menganyam adalah menyusun lungsi dan pakan. Lungsi merupakan bagian anyaman yang menjalur keatas dan pakan sebagai bagian anyaman yang menjalur kesamping yang akan mneyusup pada lungsi (Anton Gerbano, 2005, p. 37).

Pada bidang pendidikan menganyam memiliki arti yaitu menyatukan bilahbilah atau sebuah lembaran yang akan diatur seperti berupa bambu yang telah dibilah, daun yang sobekan, rotan yang telah irat, janur, kertas yang sudah diguntiung maupun dibuat pola anyaman, kulit binatang yang dikeringkan atau potongan-potongan bahan perca. Merupakan salah satu hasil kerajinan masyarakat Indonesia (Muarifah \& Nurkhasanah, 2019).

Menganyam yang dikhususkan untuk anak prasekolah dilakukan dengan pengguanaan metode yang tidak komplek, dilakukan pada langkah-langkah metode yang paling mendasar yaitu anyaman yang tidak terlalu rumit. kegiatan anyaman seperti ini mampu menggali kemampuan motorik halus anak karena melibatkan penggunaan tangan dan jari-jari selain itu adanya koordinasi dengan mata. Disamping keahlian motorik halus yang dapat berkembang, kegiatan ini juga mampu diterapkan sebagai sarana untuk pembiasaan jangkauan berfikir seorang anak, mempelajari matematika yang sederhana dan pembiasaan berfikir mendalam (Hasnawati \& Brantasari, 2018; Ni Made Sukerti, Gede Raga, 2013).

Pada dasarnya aktivitas seperti menganyam ini membutuhkan ketelitian dan rasa sabar yang tinggi bagi anak, menganyam merupakan ciri khusus kerajian yang berasal dari negara Indonesia. Sumanto mengatakan menganyam suatu kegiatan seni terampil yang memiliki fungsi untuk menciptakan suatu aneka benda mati atau benda yang bisa digunakan dalam kesenian yang dikerjakan dengan cara saling menyatukan bagian yang vertikal maupun secara horizontal dengan bahan anyaman secara satu persatu (Riasi et al., 2013).

Bahan anyaman yang bisa digunakan salah satunya dengan menggunakan bahan alam yang tersedia dilingkungan sekitar, sehingga anak mengetahui alternatif lain dalam penggunaan bahan anyaman dan tidak monoton menggunakan bahan kertas saja. Pemanfaatan bahan alam dapat digunakan untuk menganyam, selain untuk pewangi, waah makanan, ataupun hiasan. Selain itu bahan anyaman yang digunakan untuk anak usia dini harus aman sehingga tidak melukai anak. 
Berdasarkan hasil penelitian yang dilakukan oleh Oktavia Nuraini yang berjudul "Peningkatan Keterampilan Motorik Halus Melalui Kegiatan Menganyam Dengan Kertas Pada Anak Kelompk B TK Sedyo Rukun Bambanglipuro Bantul" hasil penelitian ini memiliki kriteria bahwa penelitian ini tergolong pada penelitian tindakan kelas karena dilaksanakan hanya menggunakan dua Siklus. Sampel yang diteliti adalah peserta didik kelas B sebanyak 12 peserta didik. Adapun penggunaan metode pengumpulan data penelitian ini meliputi pengamatan dan dokumentasi. Menggunakan metode analisis data yang digunakan yaitu kualitatif deskriptif serta kuantitatif. Untuk perolehan hasil penelitian dapat dilihat dari observasi yang terdapat kemajuan pada setiap siklus yaitu kondisi sebelum diterapkannya siklus bernilai 52,78\%, untuk siklus pertama sebesar 72,84\% adanya suatu peningkatan 20,06\% , selanjutnya untuk siklus ke-II bernilai 80,56\% terdapat peningkatan senilai $7,72 \%$, dapat dikatakan presentase laju peningkatan kemampuan motorik halus dengan menggunakan kegiatan menganyam anak melampai standar indikator yang telah ditetapkan tingkat keberhasilannya bernilai $76 \%$.

Dalam penelitian yang telah dilakukan diatas bahwasannya kegiatan menganyam dengan menggunakan bahan alam dapat meningkatkan motorik halus. Dalam hal ini peneliti sama-sama menggunakan bahan alam sebagai bahan menganyam dengan harapan dapat meningkatkan kemampuan motorik halus anak. Penggunaan bahan alam dalam kegiatan menganyam disamping tidak mengeluarkan biaya lebih juga ramah lingkungan, hasil anyaman anak yang sekiranya belum sesuai dengan tekhnik yang diterapkan bisa dibuang tanpa mencemari lingkungan.

\section{METODOLOGI}

Jenis penelitian yang digunakan pada penilitian adalah metode penelitian kuantitatif, dikarenakan jenis penelitian kuantitatif ini hasil akhir penelitian akhir berupa angka dan menganalisanya menggunakan program statistik. Penggunaan metode eksperimen dapat dikatakan sebagai metode yang butuhkan karena untuk mencari adanya suatu pengaruh treatmen khusus terhadap aktivitas yang lainnya dalam kondisi yang terkontrol (Dewi Purwanti et al., 2016; Sugiyono, 2018, p. 24).

Penelitian yang digunakan dalam penelitian ini adalah metode eksperimen, dengan suatu pendekatan quasi eksperimental. Quasi eksperimental merupakan salah satu tipe penelitian eksperimen dengan catatan peneliti tidak diperkenankan untuk memilih secara untuk menentukan subjek penelitian, namun hasil yang dicapai cukup bermakna, baik dilihat dari segi validitas internalnya maupun eksternal. Untuk penelitian ini penggunaan desain penelitian yaitu nonequivalent control grup design (Yusuf, 2017, p. 78).

Tabel 1. Desain Penelitian

\begin{tabular}{cccc}
\hline Grop & Pretest & Independent Variable & Posttest \\
\hline E & Y1 & $X$ & $Y 2$ \\
\hline C & $Y 1$ & - & $Y 2$ \\
\hline
\end{tabular}

Desain ini memiliki ciri khusus yaitu terdapat dua kelompok maupun kelas yang sudah ditentukan, kemudian diberikan tes awal untuk melihat kondisi yang awal apakah terdapat perbedaan antara kelas eksperimen dan kelas kontrol. Pada 
kelompok eksperimen peserta didik B1 sejumlah 15 anak yaitu dengan menerapkan aktivitas menganyam dengan bahan yang berasal dari alam, sedangkan untuk kelas kontrol yaitu peserta didik B2 sejumlah 15 anak dengan menerapakan aktivitas ataupun kegiatan konvensional atau yang biasa diterapkan.

\section{HASIL DAN PEMBAHASAN}

Uji hipotesis pada penelitian ini menggunakan independent sample t-test (dua sampel). Uji hipotesis dilakukan untuk mengetaui apakah terdapat pengaruh treatment aktivitas menganyam dengan penggunaan bahan yang berasal dari alam dan belum diolah, pada perkembangan motorik halus individu, berikut hipotesis pada penelitian ini :

H_1: Ada pengaruh perkembangan motorik halus anak usia dini melalui kegiatan menganyam

H_0: Tidak ada pengaruh perkembangan motorik halus anak usia dini melalui kegiatan menganyam.

Untuk mengetahui hasil uji hipotesis dari nilai postest kelas eksperimen maupun kelas kontrol, penjelasannya dengan menggunakan bantuan program aplikasi komputer yaitu IBM Statistics SPSS V.21. Lokasi penelitian yang dilaksanakan di TK Al-Azhar 12 Srikaton kecamatan Tanjung Bintang kabupaten Lampung Selatan yang dilakukan pada tahun ajaran 2019/2020. Menggunakan sampel kelompok B1 sebagai kelas eksperimen sebanyak 15 anak, dan sampel kelompok B2 sebagai kelas kontrol sebanyak 15 anak. Peneliti menggunakan kelompok B1 dan B2 sebagai subjek kelas eksperimen dan subjek kelas kontrol. Kelas eksperimen menggunakan kegiatan menganyam dengan bahan yang berasal dari alam dan belum diolah menjadi suatu produk, bahan alam yang digunakan yaitu daun pandan, daun pelepah pisang dan daun kelapa tidak terlalu tua agar lentur dan tidak mudah sobek saat di anyam, sedangkan kelas kontrol menggunakan kegiatan konvensional yang sudah biasa diterapkan di TK dengan menggunakan kertas hvs dan koran yang ada disekolah. Pretest yang dilakukan peneliti pada kedua kelompok, hal ini dilakukan bertujuan mendapatkan hasil dan nilai kondisi pertama pada aspek perkembangan motorik halus anak dengan kegiatan menganyam bahan alam. kemudian setelah itu diterapkannya suatu perlakuan kepada kedua kelompok dengan perlakuan kegiatan menganyam yang berbeda, kemudian peneliti melakukan tes kepada kedua kelompok dengan cara mengulang kembali kegaiatan menganyam untuk mengetahui adakah perbedaan dari kedua kelompok, perihal perkembangkan motorik halus anak menggunakan kegiatan menganyam dengan memanfaatkan media bahan alam dan media bahan kertas pada kelas kontrol.

Pada kelas eksperimen penelitian yang dilakukan dengan menggunakan kegiatan menganyam khususnya pada bahan yang gigunakan yaitu bahan alam: daun pisang, pandan, dan daun kelapa. Untuk penelitian pada kelas ekperimen menggunakan tiga RPPH (Rencana Pelaksanaan Pembelajaran Harian) dengan tema tanaman. Untuk RPPH pertama dengan sub tema daun pisang diterapkan sebanyak dua pertemuan, untuk sub tema daun pandan dan daun kelapa diterapkan sebanyak enam pertemuan, tiga pertemuan untuk RPPH daun pisang dan tiga RPPH untuk daun kelapa, jadi keselurruhan pertemuan yang dilakukan sebanyak delapan kali. Hal tersebut dilakukan guna mencapai hasil yang ingin peroleh karena untuk kegiatan yang menggunakan daun pandan dan daun kelapa menggunakan tekhnik 
anyaman ganda yang sedikit lebih berbeda dari anyaman tunggal dengan menggunakan daun pisang.

Pertama-tama guru menerapkan SOP (strandar operasional) yang sudah biasa diterapkan disekolah. Setelah itu memasuki kegiatan awal guru menyiapkan alatalat serta bahan yang akan digunakan dan berkaitan dalam kegiatan pembelajaran sebagai tes awal untuk mengetahui keadaan awal perkembangan motorik halus anak melaui kegiatan menganyam dengan bahan kertas origami yang sebelumnya telah diterapkan disekolah. Kegiatan selanjutnya yaitu menganyam dengan menggunakan bahan alam dari daun pisang, daun pandan dan daun kelapa. Guru memberitahu kegiatan yang akan dilakukan kepada peserta didik yaitu kegiatan menganyam, tidak lupa guru menceritakan dan memberikan pengetahuan awal tentang kegiatan menganyam, setelah itu guru menjelaskan dan memberikan contoh langkah-langkah kegitan pembelajaran serta mengenalkan fungsi dan kegunaan alat dan bahan yang akan digunakan.

Guru mengarahkan anak untuk merobek ataupun membagi daun jadi beberapa bagian, setelah itu guru menagarahkan anak untuk mulai menganyam dengan menyusupkan bilah pada bagian lungi kearah pakan ataupun menumpang tindihkan bahan anyaman secara vertikal dan horizontal secara bergantian. Untuk bahan anyaman dari daun pisang dianyam bentuk tikar mini, pada kegiatan ini hanya menggunakan tekhnik anyaman tunggal dan terbilang sederhana untuk anak usia dini, untuk bahan kedua yaitu daun pandan yang mana dijadikan bentuk baling-baling atau kincir angin mainan, bahan yang ketiga daun kelapa yang dijadikan bentuk anyaman ikan. Setelah itu gunting digunakan sesudah anak menyelesaikan anyaman bertujuan untuk menggunting bagian yang terlalu panjang atauapun untuk merapihkan bagian yang diinginkan serta membentuk sirip dan ekor pada kegiatan anyaman daun kelapa yang membentuk anyaman ikan. Kemudian semua hasil anyaman anak diberi double tip pada salah satu sisi untuk direkatkan pada kertas, hal ini bertujuan untuk menaruh hasil anyaman yang telah dibuat oleh anak-anak. Kegiatan ini dilakukan tidak hanya sekali namun dilakukan secara berulang untuk membiasakan anak agar bisa dan terbiasa, dengan bantuan dan arahan dari guru agar anak akan terbiasa menganyam, pada akhir kegiatan dan pertemuan guru mengadakan tes berupa kegiatan menganyam menggunakan bahan alam dengan tujuan untuk mengetahui serta mengukur perkembangan motorik halus anak usia dini kelompok B pada kegiatan menganyam menggunakan bahan alam.

Berbeda pada kelas kontrol, dimana kegiatan pembelajarannya menggunakan bahan kertas yang sudah disediakan oleh guru bagian yang akan dianyam telah dipotong-potong memanjang sebagai lungsi dan bagian pakan pun telah digunting untuk nantinya disisipkan secara horizontal. Dalam hal ini anak tidak dilibatkan dalam proses mempersiapkan bahan, anak hanya melakukan anyaman saja, dari hasil observasi yang telah dilakukan pada kelas kontrol, hal ini dilakukan sebagai tes awal (pretest). Selanjutnya pada pertemuan guru kembali memberikan tes akhir (postest), kedua tes yang dilakukan bertujuan untuk memperoleh data nilai.

Pada kegiatan menganyam yang diterapkan pada kelas ekperimen, penggunaan media bahan alam yang mudah didaptkan dan juga terdapat dilingkungan sekitar memiliki fungsi lainnya dari yang sebelumnya anak-anak sudah mengetahui maupun belum mengetahi tentang hal tersebut, dengan demikian anak dapat bereksplorasi dalam kegiatan menganyam yang membutuhkan 
penggunaan koordinasi mata maupun tangan yang berhubungan erat dengan motorik halus.

Keuntungan dari penggunaan media bahan alam adalah tidak mengeluarkan biaya yang mahal, bahkan tidak mengeluarkan biaya sama sekali. Selain itu bahanbahan yang dibutuhkan mudah didapat. Penggunaan media ini mendukung anak memulai belajar, menstimulasi imajinasi, mudah untuk mengingat tentang pengalaman yang bermakna dan membangun komunikasi, serta motorik halus anak (Fauziah, 2013)

Setelah selesai pelaksaan kegiatan menganyam dengan menggunakan bahan alam pada kelas eksperimen perkembangan motorik halus anak diharpakan terdapat pengaruh dan jugameningkat, terdapat tujuan dari perkembangan motorik halus anak yaitu ada alasan aspek sosial, aspek akademis, aspek pekerjaan dan aspek psikologis. Dari perkembangan anak terdapat beberapa yang mengalami kesulitan seperti membuka dan menutup tutup bekal, mengancingkan baju, toilet training, mengikat tali sepatu, membuka dan menutup resleting, mewarnai, memegang pensil, menggunting dll. Sehingga jika perkembangan motorik halus anak usia dini dapat distimulus dengan baik maka berbagai aktivitas maupun kegiatan yang berkaitan erat dengan motorik halus dapat terlaksana dengan baik dan sesuai dengan keinginan.

Sebelum melakukan pretest dan postest maka terlebih dahulu melakukan pengujian validitas instrumen serta reliabilitias instrumen yang berjumlah 10 item, berikut pedoman observasi kegiatan menganyam terhadap motorik halus anak usia dini:

Tabel 1. Pedoman Observasi Kegiatan Menganyam terhadap Kemapuan

Nama Motorik Halus Anak Usia 5-6 Tahun d i Tk Al-Azhar 12

Kelompok

A. Hari/tgl

\begin{tabular}{|c|c|c|c|c|c|}
\hline \multirow[t]{2}{*}{ No } & \multirow[t]{2}{*}{ Item } & \multicolumn{4}{|c|}{ Penilaian Anak } \\
\hline & & BB & MB & $\mathrm{BSH}$ & BSB \\
\hline 1 & $\begin{array}{l}\text { Dapat menyusun anyaman secara vertikal } \\
\text { "lungsi" }\end{array}$ & & & & \\
\hline 2 & Dapat menumpang tindihkan bahan & & & & \\
\hline 2 & anyaman secara horizontal "pakan" & & & & \\
\hline 3 & Dapat membilah daun pisang & & & & \\
\hline 4 & Dapat membilah daun pandan & & & & \\
\hline 5 & $\begin{array}{l}\text { Anak dapat membalik warna sisi daun } \\
\text { untuk disisipkan. }\end{array}$ & & & & \\
\hline 6 & Anak dapat menyelasaikan anyaman & & & & \\
\hline 7 & $\begin{array}{l}\text { Anak merapihkan sisi anyaman dengan } \\
\text { menggunkan gunting }\end{array}$ & & & & \\
\hline 8 & $\begin{array}{l}\text { Anak dapat membuat anyaman bentuk } \\
\text { baling-baling }\end{array}$ & & & & \\
\hline 9 & $\begin{array}{l}\text { Anak dapat membuat anyaman bentuk } \\
\text { tikar }\end{array}$ & & & & \\
\hline 10 & $\begin{array}{l}\text { Anak dapat membuat anyaman bentuk } \\
\text { segitiga (ikan) dengan tekhnik ganda }\end{array}$ & & & & \\
\hline
\end{tabular}


Dari 10 item diatas dinyatakan valid dikarenakan dari keseluruhan tiap item nilai $r$ hitungnya lebih besar dari pada nilai $r$ tabel sebesar 0,514 dan juga dinyatakan reliabel karena hasil nilai reliabilitas lebih besar dari pada taraf signifikansinya yaitu sebesar 0,05 atau $5 \%$, sehingga dengan demikian dapat dilanjutkan untuk tahap selanjutnya, yaitu penilain pretest dan postest dan untuk menguji hipotesis dan tentunya sebelum memasuki tahap penilaian tersebut data yang akan digunakan harus berdistribusi normal dan juga bersifat homogen, beberapa uji yang telah dilakukan menggunakan bantuan program aplikasi komputer yaitu IBM SPSS Statistics versi 21.

Berikut adalah tabel data nilai hasil pretes pada kelas eksperimen maupun pada kelas kontrol:

Tabel 2. Data Nilai Pretest Kelas Eksperimen Dan Kontrol

\begin{tabular}{llrr}
\hline Statistics & & \multicolumn{2}{c}{ Kontrol } \\
\hline $\mathrm{N}$ & Valid & Eksperimen & 15 \\
Mean & Missing & 0 & 0 \\
Median & & 20.60 & 23.67 \\
Mode & 21.00 & 23.00 \\
Std. Deviation & 21 & $22^{\mathrm{a}}$ \\
Minimum & 3.961 & 3.222 \\
Maximum & 15 & 20 \\
\hline
\end{tabular}

Pada tabel diatas nilai rata-rata mean pada eksperimen sebesar 20,60 sedangkan pada kelas kontrol 23,67. Kedua nilai mean tersebut tidak berbeda secara signifikan.Perhitungan nilai tengah atau median pada kelas eksperimen 21,00 dan kelas kontrol 23,00. Kedua nilai tengah pada kelas eksperimen dan kontrol tidak berbeda secara signifikan.Nilai yang sering muncul atau modus pada tabel diatas menunjukan hasil yang tidak jauh berbeda kelas eksperimen 21 dan kelas kontrol 22.Nilai standart deviation pada kelas eksperimen 3,961 dan kelas kontrol 3,222. Nilai minumun pada kelas eksperimen 15 dan pada kelas kontril 20, sedangkan untuk nilai maksimum pada kelas eksperimen 30 dan pada kelas kontrol 32.Dapat disimpulkan dari hasil nilai mean, median, mode, perolehan nilai minimum dan juga nilai maksimum pada kelas kontrol lebih tinggi dibandingkan kelas eksperimen, sedangkan untuk nilai standart deviation lebih tinggi kelas eksperimen lebih tinggi dari kelas kontrol.

Penjabaran diatas menunjukkan adanya perbedaan dalam melakukan kegiatan pembelajaran menganyam baik dikelas eksperimen dan kontrol. Untuk kelompok eksperimen memberikan bahan yang berasal dari alam berupa, daun pisang, daun kelapa serta daun yang biasa dijadikan pewarna dan pewangi masakan yaitu pandan. Bahan alam yang digunakan ini membuat anak mendapatkan pengalaman dan pengetahuan baru bahwasannya daun tersebut bukan hanya dapat digunakan sebagai bahan makanan (daun pandan), pembungkus makanan (daun pisang dan daun kelapa) yang biasanya mengenal bentuk ketupat nasi dari daun kelapa, atau dibiarkan begitu saja, hal ini membuat anak dapat mengeksplor motorik halusnya dengan cara memotong dan merobek atau membilah daun-daun yang digunakan untuk dijadikan sebagai bahan kegiatan menganyam yang dapat dikreasikan menjadi bebera bentuk dan macam. 
Kegiatan menganyam menggunakan bahan alam ini selain mudah didapat karena banyak terdapat dilingkungan sekitar juga ramah lingkungan, sehingga anak mengetahui hal-hal yang baru bahwa kegiatan menganyam bisa menggunakan bahan yang berasal dari alam dan belum diolah menjadi bentuk apapun. Kegiatan menganyam yang dilakukan di TK Al-azhar 12 Srikaton Lampung Selatan sebelum diterapkan kegiatan tersebut anak-anak masih mengalami sedikit kendala, namun setelah dilterapkannya kegiatan menganyam yang menggunakan bahan alam anak mampu melakukan kegitan sendiri yang berhubungan dengan aspek perkembangan motorik halus anak usia dini yang berhubungan dengan kegiatan sehari-hari seperti mengikat tali sepatu, membuka bekal makanan, bahkan kegiatan toilet training seperti membuka dan menutup resleting, mengancingkan baju, mencuci tangan sebelum dan sesudah makan.

Setelah dilakukan treatmen, perkembangan motorik halus anak mulai terlihat di kesehariannya. Di tunjukan dengan karena motorik halus anak sangat penting bagi kehidupan sehari-sehari. Karena kegiatan seperti mengikat tali sepatu membuka bekal, toilet training, membasuh tangan merupakan kegiatan yang harus anak usia sedini mungkin (Rudiyanto, 2016, p. 13). Bersamaan dengan suatu urgensi mengembangkan motorik halus terdapat 4 manfaat terkait pentingnya perkembangan motorik halus anak usia dini yaitu: alasan pada aspek sosial, alasan pada bidang akademis, alasan profesi dan alasan pada aspek emosional (Sit, 2017, p. 13). Dari ke empat alasan tersebut terlihat pentingnya perkembangan pada motorik halus individu di stimulus sejak dini. Jika tidak mengalami perubahan motorik halus anak berkembangan dan stimulus secara optimal tidak hanya anak terampil dalam kemampuan yang menunjang kehidupan sehari-hari, namun terampil dalam berbagai aspek yang berhubungan erat dengan koordinasi mata dan tangan yaitu motorik halus.

Setelah itu dilakukan penelaian akhir atau postest Berikut nilai hasil posttest pada kelas eksperimen maupun kelas kontrol:

Tabel 3. Data Nilai Postest Kelas Eksperimen Dan Kontrol

\begin{tabular}{llrr}
\hline & & \multicolumn{2}{c}{ Statistics } \\
Eksperimen & & Kontrol \\
\cline { 3 - 4 } $\mathrm{N}$ & Valid & 15 & 15 \\
Mean & Missing & 0 & 0 \\
Median & & 32.93 & 29.93 \\
Mode & & 33.00 & 31.00 \\
Std. Deviation & & 33 & $28^{\mathrm{a}}$ \\
Minimum & 1.438 & 2.120 \\
Maximum & 30 & 27 \\
\hline
\end{tabular}

Data post test menunjukan adanya perkembangan Pada tabel diatas nilai ratarata mean pada kelas eksperimen sebesar 32,93 sedangkan pada kelas kontrol 29,93. Kedua nilai mean tersebut tidak berbeda secara signifikan.Perhitungan nilai tengah atau median pada kelas eksperimen 33,00 dan kelas kontrol 31,00. Kedua nilai tengah pada kelas eksperimen dan kontrol tidak berbeda secara signifikan.Nilai yang sering muncul atau modus pada tabel diatas menunjukan hasil yang tidak jauh berbeda kelas eksperimen 33 dan kelas kontrol 28.Nilai standar deviation pada kelas eksperimen 1,438 dan kelas kontrol 2,120. Nilai minumun pada kelas eksperimen 30 
dan pada kelas kontrol 27, sedangkan untuk nilai maksimum pada kelas eksperimen 36 dan pada kelas kontrol 33. Dapat disimpulkan dari hasil nilai mean, median, mode, nilai minimum dan nilai maksimum pada kelas kontrol lebih rendah dibandingkan kelas eksperimen, sedangkan untuk nilai standart deviation kelas eksperimen lebih rendah dari kelas kontrol. Uraian diatas terlihat perbedaannya yang tampak setelah diberikan perlakukan dengan kegiatan menganyam menggunakan bahan alam seperti daun pisang, daun pandan dan daun kelapa. Dapat dikatakan bahwa kegiatan menganyam dengan menggunakan bahan alam ini cukup berpengaruh terhadap perkemangan motorik halus anak di TK Al-Azhar 12 Srikaton Lampung Selatan.

Menganyam untuk anak usia 5-6 tahun tidak dilakukan dengan teknik yang kompleks, namun masih dalam tahap teknik dasar menganyam diajarkan dengan sangat sederhana kepada anak. kemampuan menganyam dapat mengasah keterampilan motorik halus anak karena menggunakan tangan dan jari-jemari demikian juga dengan koordinasi mata. Selain keterampilan motorik halus yang dapat dikembangkan, menganyam juga dapat digunakan sebagai alat untuk melatih logika anak, belajar matematika, dan melatih konsentrasi (Hasnawati \& Brantasari, 2018).

Setelah dilakukan posttest perlu dilakukan pengujian akhir untuk melihat adanya pengaruh dari treatmen yang telah dilakukan, maka perlu melakukan uji Tdari tretmen tersebut dengan berbantu program aplikasi computer yakni IBM SPSS Statistics 21. Berikut hasil pemaparan uji T:

Tabel 4. Hasil uji T-Test Pada kelompok eksperimen dan kelompok kontrol

\begin{tabular}{|c|c|c|c|c|c|c|c|c|c|c|}
\hline & & \multicolumn{2}{|c|}{$\begin{array}{c}\text { Levene's Test } \\
\text { for Equality } \\
\text { of Variances }\end{array}$} & \multicolumn{7}{|c|}{ t-test for Equality of Means } \\
\hline & & \multirow[t]{2}{*}{$\mathrm{F}$} & \multirow[t]{2}{*}{ Sig. } & \multirow[t]{2}{*}{$\mathrm{T}$} & \multirow[t]{2}{*}{ Df } & \multirow[t]{2}{*}{$\begin{array}{c}\text { Sig. } \\
(2- \\
\text { tailed })\end{array}$} & \multirow[t]{2}{*}{$\begin{array}{l}\text { Mean } \\
\text { Differ } \\
\text { ence }\end{array}$} & \multirow{2}{*}{$\begin{array}{c}\text { Std. } \\
\text { Error } \\
\text { Differ } \\
\text { ence } \\
\end{array}$} & \multicolumn{2}{|c|}{$\begin{array}{l}\text { 95\% Confidence } \\
\text { Interval of the } \\
\text { Difference }\end{array}$} \\
\hline & & & & & & & & & Lower & Upper \\
\hline \multirow{2}{*}{$\begin{array}{l}\text { MOTORI } \\
\text { K HALUS }\end{array}$} & $\begin{array}{l}\text { Equal } \\
\text { variances } \\
\text { assumed } \\
\end{array}$ & 8.860 & .006 & 4.536 & 28 & .000 & 3.000 & .661 & 1.645 & 4.355 \\
\hline & $\begin{array}{l}\text { Equal } \\
\text { variances } \\
\text { not } \\
\text { assumed }\end{array}$ & & & 4.536 & 24.627 & .000 & 3.000 & .661 & 1.637 & 4.363 \\
\hline
\end{tabular}

Perhitungan t-test mendapatkan nilai sig (2-tailed)sebesar 0,000. Nilai sig (2tailed) ini lebih kecil dari nilai signifikan $=0,05$ atau $5 \%(0,000<0,05)$, dapat diartikan bahwa $\mathrm{H}_{1}$ diterima dan $\mathrm{H}_{0}$ ditolak. $\mathrm{H}_{1}$ Ada pengaruh perkembangan motorik halus anak usia dini melalui kegiatan menganyam. Dengan demikian terdapat pengaruh yang berbeda antara kelompok eksperimen dan kontrol pada perkembangan motorik halus anak dengan menggunakan kegiatan menganyam. Yang artinya penerapan menganyam menggunakan bahan alam terdapat pengaruh pada perkembangan motorik halus anak usia dini 


\section{SIMPULAN}

Treatment aktivitas menganyam menggunakan bahan-bahan alam pada kelas eksperimen terbukti lebih baik dalam mengembangkan motorik halus anak usia dini dibandingkan dengan kegiatan konvensional. Hal tersebut sesuai dengan hipotesis yang menyatakan bahwa terdapat pengaruh perkembangan motorik halus anak usia dini dngan kegiatan menganyam dengan menggunakan bahan-bahan alam.

\section{UCAPAN TERIMA KASIH}

Penulis mengucapkan terimakasih banyak kepada Taman Kanak-Kanak Alazhar 12 Srikaton Lampung Selatan atas kerjasama yang baik selama penelitian ini dilakukan. Kepercayaan lembaga yang diberikan akan terus kami jaga dan akan kami kembangkan terus pada penelitian- penelitian yang akan datang.

\section{DAFTAR PUSTAKA}

Amalia, I. A. (2016). Aspek Perkembangan Motorik Dan Hubungannya Dengan Aspek Fisik Dan Intelektual Anak. Awlady: Jurnal Pendidikan Anak, 2(1), 1-12. https://doi.org/10.24235/awlady.v2i1.760

Anggraini, W., \& Kuswanto, C. W. (2019). Teknik Ceklist Sebagai Asesmen Perkembangan Sosial Emosional di RA. Al-Athfaal: Jurnal Ilmiah Pendidikan Anak Usia Dini, 2(2), 61-70. https://doi.org/10.24042/ajipaud.v2i2.5248

Anton Gerbano, A. S. D. (2005). Aneka Anyaman Bambu. Kanisius.

Berti Setya N, Farida Mayar, D. E. (2019). Pelaksanaan Stimulasi Motorik Halus Pada Latihan Kehidupan Praktis Di Taman Kanak-Kanak Pioneer Montessori School Padang. Pedagogi: Jurnal Anak Usia Dini Dan Pendidikan Anak Usia Dini, 5(1), 55. https://doi.org/10.30651/pedagogi.v5i1.2520

Darmiatun, S., \& Mayar, F. (2019). Meningkatkan Kemampuan Motorik Halus Anak melalui Kolase dengan Menggunakan Bahan Bekas pada Anak Usia Dini. Jurnal Obsesi : Jurnal Pendidikan Anak Usia Dini, 4(1), 257. https:/ / doi.org/10.31004/obsesi.v4i1.327

Dewi Purwanti, R., Dinda Pratiwi, D., \& Rinaldi, A. (2016). Pengaruh Pembelajaran Berbatuan Geogebra Terhadap Pemahaman Konsep Matematis Ditinjau Dari Gaya Kognitif Peserta Didik Kelas Vii Smp Negeri 2 Bandar Lampung. Al-Jabar, 7(1), 97107.

Faizatin, N. (2018). Peningkatan Motorik Halus Melalui Kegiatan Origami Pada Anak Kelompok A TK DWP Kedungrukem Benjeng Gresik Tahun Pelajaran 2015/2016. Pedagogi: Jurnal Anak Usia Dini Dan Pendidikan Anak Usia Dini, 4(2), 80. https://doi.org/10.30651/pedagogi.v4i2.1964

Fauziah, N. (2013). Penggunaan Media Bahan Alam Untuk Meningkatkan Kreativitas Anak. Jiv, 8(1), 23-30. https://doi.org/10.21009/jiv.0801.4

Hajar Pamadhi, E. S. S. (2008). Seni Keterampilan Anak. Universitas Terbuka.

Hasnawati, H.-, \& Brantasari, M.-. (2018). Meningkatkan Konsentrasi Anak Dengan Kegiatan Menganyam Kain Perca Pada Anak Usia 5-6 Tahun Di Tk Tunas Muda Kersik Kec.Mararangkayu Kab. Kutai Kartanegara. Jurnal Warna: Pendidikan Dan Pembelajaran Anak Usia Dini, 2(2), 38-52. https:/ / doi.org/10.24903/jw.v2i2.193

Masdudi. (2015). Karakteristik Perkembangan Pendidikan Anak Usia Dini. AWLADY : Jurnal Pendidikan Anak, 1(2), 1-26. https://doi.org/10.24235/awlady.v1i2.739

Maulida, M. (2020). Optimalisasi Perkembangan Motorik Halus Anak Melalui Permainan Lagu Daerah “Ampar-Ampar Pisang." Cakrawala Dini: Jurnal Pendidikan Anak Usia Dini, 11(1), 10-16. https://doi.org/10.17509/cd.v11i1.20133

Muarifah, A., \& Nurkhasanah, N. (2019). Identifikasi Keterampilan Motorik Halus Anak. Journal of Early Childhood Care and Education, 2(1), 14. 
https:/ / doi.org/10.26555/jecce.v2i1.564

Ni Made Sukerti, Gede Raga, I. N. M. (2013). Penerapan Metode Demonstrasi Berbantuan Media Daun. Jurnal Pendidikan Anak Usia Dini Undiksha, 1(1), 1-10. https:// doi.org/http://dx.doi.org/10.23887/paud.v1i1.1141

Nurhayati, E. (2015). MEMAHAMI TUMBUH KEMBANG ANAK USIA DINI Perspektif Psikologi Perkembangan. AWLADY: Jurnal Pendidikan Anak, 1(2), 1-14. https:// doi.org/10.24235/awlady.v1i2.738

Rakimahwati, R., Lestari, N. A., \& Hartati, S. (2018). Pengaruh Kirigami Terhadap Kemampuan Motorik Halus Anak di Taman Kanak-Kanak. Jurnal Obsesi: Jurnal Pendidikan Anak Usia Dini, 2(1), 98. https:/ / doi.org/10.31004/obsesi.v2i1.13

Riasi, P., Raga, I. G., \& Suarjana, I. M. (2013). Penerapan Metode Group Investigation Melalui Kegiatan Keterampilan Tangan Untuk Meningkatkan Kemampuan Perkembangan Motorik Halus Anak Di Tk Bhakti Kumara Kalisada. Jurnal Pendidikan Anak Usia Dini Undiksha, 1(1), 1-11. https://doi.org/http:// dx.doi.org/10.23887/paud.v1i1.1087

Rudiyanto, A. (2016). Perkembangan Motorik Kasar dan Motorik Halus Anak Usia Dini. Darussalam Press Lampung.

Sari, H. M., \& Nofriyanti, Y. (2019). Peningkatan Kreativitas Anak Usia Dini melalui Kegiatan Menganyam dengan Origami. Jurnal Obsesi: Jurnal Pendidikan Anak Usia Dini, 4(1), 146. https:// doi.org/10.31004/obsesi.v4i1.247

Sintia, N., Kuswanto, C. W., \& Meriyati, M. (2019). Meningkatkan Kemampuan Sosial Anak Usia Dini dengan Model Outbound. Jurnal CARE (Children Advisory Research and Education), 6(2), 1-10. http://ejournal.unipma.ac.id/index.php/JPAUD/article/download/3939/2034

Sit, M. (2017). Psikologi Perkembangan Anak Usia Dini. Kencana.

Sugiyono. (2018). Metode Penelitian Pendidikan (Pendekatan Kuantitatif, Kualitatif, dan RED). Alfabeta.

Udin, T. (2015). Mengenali Anak Usia Dini Melalui Pertumbuhan. Awlady: Jurnal Pendidikan Anak, 1(2), 1-21. https://doi.org/10.24235/awlady.v1i2.744

Wijaya Kuswanto, C., \& Dinda Pratiwi, D. (2020). Pengembangan Bahan Ajar Pendidikan Jasmani untuk Anak Usia Dini Berbasis Tematik. Al-Athfal : Jurnal Pendidikan Anak, 6(1), 55-68. https:/ / doi.org/10.14421/al-athfal.2020.61-05

Wiyani, N. A. (2016). Konsep Dasar PAUD. Gava Media.

Yuningsih, A., \& Hasanah, U. (2018). Penggunaan Playdogh Dalam Mengembangkan Motorik Halus. Al-Athfaal: Jurnal Ilmiah Pendidikan Anak Usia Dini, 1(1), 117-128. https:/ / doi.org/10.24042/ajipaud.v1i1.3408

Yusuf, M. (2017). Metode Penelitian Kuantitatif, Kualitatif, dan Penelitian Gabungan. Kencana. 